\title{
The Main Geological Events of the Chinese Archaean and Proterozoic Eons
}

\author{
Keqiang $\mathrm{He}^{1}$, Rulin $\mathrm{Du}^{2}$ \\ ${ }^{1}$ Geological Environment Center, Qingdao Technological University, Qingdao, China \\ ${ }^{2}$ School of Economics Shijiazhuang, The Precambrian Institute of Shijiazhuang, Shijiazhuang, China \\ Email: keqianghe@sina.com
}

Received January 17, 2012; revised February 20, 2012; accepted March 22, 2012

\begin{abstract}
A systematic review and comparison of the time, sequence, nature, and characteristics of the major geological events of worldwide Archean and Chinese Precambrian and their interrelationships reveals that these events reveals the spatial-temporal pattern of the events and their significance in geological evolution. The study also touches upon relationship between Early Precambrian Era and plate tectonics. A comparison between the Precambrian major geological events and those elsewhere on the earth proves that the crustal evolution is characterized by striking irreversibility, gradualism, and synchronism. The geological events in China have their unique features, which show that China has a relatively complete record of formation and evolution of rocks, strata, structures, and organisms spanning $3800 \mathrm{Ma}$ to $540 \mathrm{Ma}$. The Archean underwent multiple-stage complex metamorphism and deformation; metamorphism is on the higher end; komatiite is absent in the greenstone belts; cratonization occurred rather late and varied between the north and the south. The research results above provide main theoretical basis for deeply systematic researching the early dynamic evolution laws of the earth and the dynamic evolution characteristics of the tectonic plates.
\end{abstract}

Keywords: China; Archaean; Proterozoic; Precambrian; Geological Events

\section{Introduction}

The Precambrian Era, which spans roughly over eightyfive percent of the earth's recorded history out of it entire history, is a critical stage in the earth's evolution history, captivating geologists all over the world for its complex experience, rich mineral resources it produced, and it's relevance to the research on the origin and evolution of the earth and life.

More than seventy percent of the land on the present-day earth is composed of Archean terrains and their metamorphosed equivalents. Therefore, that the evolution of the Archaean or Early Precambrian crust has in recent years become one of the biggest hotspots and challenges in geological research, which, in turn, has become an important source of inspiration for new research.

China is one of the countries which are bestowed with the most widespread Precambrian strata, facilitating research in this subject and nurturing a tradition of such research. The country has a relatively complete historical record (dating from $3800 \mathrm{Ma}$ to $543 \mathrm{Ma}$ ) of formation and evolution of rocks, strata, structures, and organisms, which hosts a wide variety of minerals and displays an assortment of unique geological conditions.
This study synthesizes the author's own and other researchers' publications, systematically examines and compares the time, sequence, nature, and features of the Archean worldwide and Chinese Precambrian major geological events and their interrelationships, and identifies a spatial pattern of consistency, differentiation, and imbalance along with a temporal pattern of periodicity and cycles. These findings may provide a useful basis for the investigation of the evolution trend and for the division of the evolution stages of the earth in its early days, and offer significant clues to the relations between early-day structural framework and plate tectonics of the crust.

\section{Main Geological Events of the Chinese Archaean Eon (Tables 1 and 2)}

\subsection{The Time Sequence and Features of Main Geological Events in Archaean Eon}

Since 1980s four pieces of detrital zircon were separated from metamorphic quartz sandstone deposited about $2800 \mathrm{Ma}$ at Mount Narryer in West Australia. The U-Pb age tested by ionic probe mass spectrum was $4200 \mathrm{Ma}$, and it represents the oldest known mineral age in the Earth $[1,2]$. Subsequently, the history of original crust could be pushed forward ca. $4300 \mathrm{Ma}$ (see Table 1). 
Ancient crustal rocks older than 3800 Ma globally are very rare. They have only been discovered in SW Greenland, NW Canada, and Enderby Land, South Pole $[3,4]$. The Isua Belt of Godthab district in SW Greenland was the earliest layered series which qualified as crustal rocks. They comprise mainly metamorphic volcanic rocks and sedimentary rocks $>3000 \mathrm{~m}$ in thickness, and have a U-Pb age of ca. 3820 Ma based on detrital zircons. The granites that intrude the Isua Belt are some of the earliest known granites with a $\mathrm{Rb}-\mathrm{Sr}$ age of $3780 \mathrm{Ma}$ and have been transformed into the Amitsoq gneiss after metamorphism [5]. The gneiss which is exposed in large areas can be divided into three rock groups: tonalite, trondhjemite and granodiorite (TTG rock). These socalled "grey gneiss" became the primitive palaeo-continental nucleus. Between the continental nucleus and their margins, there are many greenstone belts which became hyperplasia body on the continental nucleus and the welded belts of continental nucleus.

Since 1990s, the trondhjemite found in the Anshan Mountain of China and dated ca. 3800 Ma could be divided into two types: Baijiafen trondhjemite (also known as ortho-gneiss) and Dongshan trondhjemite migmatite. In addition, Liu D. Y, Nutman A. P., Compston W. obtained a U-Pb age between $3500 \mathrm{Ma}-3850 \mathrm{Ma}$ from a single-grain zircon found in Huang Boyu, eastern Hebei Province [6]. It was the earliest dated rock in China. Caozhuang Rock represents the earliest super crustal Rocks. These rocks show the evolution of an early continental nucleus (craton) in China.

The greenstones (early greenstone) of the Palaeo-
Middle Archean Era are represented globally by the Swaziland greenstone of Barberton, South Africa in African shield [7], and Warawoona greenstone of Yilgarn shield, West Australia [8]. The amphibolites of Xiaolaihe greenstone belt in Liaoning, NE China which have a $3000 \mathrm{Ma} \mathrm{Sm}-\mathrm{Nd}$ isochron age belong to this early greenstones event [9], and comprise komatiites, mafic rock and offshore marine sedimentary deposits as the main characteristics. Combined they form a complete volcanic-sedimentary cycle. The appearance of advanced metamorphic zone of late Palaeo-Middle Archean Era (granulite facies) was part of the global granulite-facies metamorphic event that happened in the earliest phase of lithosphere formation. It is marked worldwide by strong tectogenesis (tectono-thermal event) and regional metamorphism, and represents the first collision of ancient continental nucleus and land masses, and which made the original lithosphere sink and was shaped into granulite facies after deep melting and into charnockite after remelting. This "Movement" (event) can be recognized in North America, Europe, West Australia, and Africa. In Africa, it was called the Dahomey Movement. In China, many scientists agreed to name this movement the Qianxi Movement. According to the tectogenesis and intensity of magma activities and universality of regional metamorphism, the time period of $2900-3000 \mathrm{Ma}$ can be regarded as the demarcation age between the PalaeoMiddle Archean Era and the Neo-Archean Era. The trondhjemite event of early Neo-Archean Era is recorded in Southwest Finland, Norway, and West Greenland. Along with the grey gneiss, it has formed the bulk of

Table 1. The time sequence of main geological events in Archean Eon.

\begin{tabular}{|c|c|c|c|c|c|}
\hline Geologic Chronology & $\begin{array}{c}\text { Event } \\
\text { Sequence }\end{array}$ & Main Geologic Events & $\begin{array}{c}\text { Crustal } \\
\text { Movement }\end{array}$ & Isotopic Age & Main Districts \\
\hline \multirow[t]{2}{*}{ Archean Eon } & & & Kon Nore & & \\
\hline & 8 & $\begin{array}{l}\text { Kali granite Intrusive and large-scale } \\
\text { regional metamorphism }\end{array}$ & $\begin{array}{l}\sim \text { Ken Nore } \\
\text { Movement } ~\end{array}$ & $\begin{array}{c}2500 \mathrm{Ma} \\
2600-2500 \mathrm{Ma}\end{array}$ & $\begin{array}{c}\text { Canada, West Australia, China, } \\
\text { Finland }\end{array}$ \\
\hline \multirow[t]{3}{*}{ Neo-Archeozoic Eon } & 7 & $\begin{array}{l}\text { Late Archean Greenstone Terrane } \\
\text { (Late Greenstone) }\end{array}$ & $\sim \sim \sim \sim$ & $2800-2700 \mathrm{Ma}$ & $\begin{array}{c}\text { North America, South } \\
\text { Africa, West Australia, Russian }\end{array}$ \\
\hline & 6 & Trondhjemite Event & Dahomey & $2800-2900 \mathrm{Ma}$ & $\begin{array}{l}\text { West Finland, Greenland, } \\
\text { China }\end{array}$ \\
\hline & 5 & $\begin{array}{l}\text { Early Archean Granulite Event } \\
\text { (Global Regional Metamorphism) }\end{array}$ & & $3000-2900 \mathrm{Ma}$ & Covering globally \\
\hline \multirow{4}{*}{$\begin{array}{c}\text { Paleo-Middle } \\
\text { Archaeozoic Eon } \\
\text { and Pre-Archean Eon }\end{array}$} & 4 & $\begin{array}{l}\text { Ancient Archean Granite-Greenstone } \\
\text { Terrance (Early Greenstone) } \\
\text { (Some districts suffered high-grade } \\
\text { regional metamorphism) }\end{array}$ & $\sim \sim \sim \sim$ & $3400-3100 \mathrm{Ma}$ & $\begin{array}{l}\text { South Africa, West Australia } \\
\text { India, and China }\end{array}$ \\
\hline & 3 & $\begin{array}{l}\text { The earliest granite intrusion and } \\
\text { metamorphic event (Amitsoq Granite) }\end{array}$ & $\sim \sim \sim \sim$ & $3800-3700 \mathrm{Ma}$ & Greenland, Canada, China \\
\hline & 2 & $\begin{array}{c}\text { The earliest layered rock system } \\
\text { (Greenland Isuah Group) }\end{array}$ & & $3820 \mathrm{Ma}$ & Southwest Greenland \\
\hline & 1 & $\begin{array}{l}\text { The earliest geological record } \\
\text { (zircon age) }\end{array}$ & & $4200 \mathrm{Ma}$ & West Australia \\
\hline
\end{tabular}


Archean rocks or intruded into ancient greenstone belts.

In Qian'an of eastern Hebei Province, Qingyuan of northern Liaoning Province, Anshan of Southern Liaoning Province, and Taishan of western of Shandong Province, there is a lot of charnockite exposed (see Table 2). For example, in Qian'an of eastern Hebei Province ancient charnockite was found intruded in the grey gneiss of Qianxi granulite facies. Cored with its rock mass, Qingyuan charnockite featured within migmatite belt and granulite (grey gneiss) to the outer zone [10]. Reference [10] shows that charnockite was formed by remelting, crystal fractionation and metasomatism. Its intrusion is dated as the same as that of granulite formation, ca. 2800 - $2900 \mathrm{Ma}$.

In the Chinese Archean Craton, there was a trend that the granite evolved from the early tonalite and trondhjemite, to the late kaligranite. From its components, we also can conclude that it accords with the model of continental growth; in the early stage abundant in sodium, later in calcium. Zhou et al. separated an apatite sample from the $3.8 \mathrm{Ga}$ (zircon SHRIMP U-Th-Pb age) metaquartz-diorite sample in Anshan area and using SHRIMP II. 32 analyses yielded a $207 \mathrm{~Pb} / 206 \mathrm{~Pb}$ weighted mean age of $3007 \pm 22 \mathrm{Ma}$. This is interpreted as the age of recrystallization of the apatite during the very intense thermo-tectonic events at $\sim 3.0 \mathrm{Ga}$ in the Anshan area.

In the late Archean Era, greenstones (late greenstone) are widespread and exposed in many shield regions of the world (see Table 2). They comprise mainly mafic rock, acid-intermediate volcanic rock, and clastic sedimentary

Table 2. Isotopic age of main geological events in Archean Eon.

\begin{tabular}{|c|c|c|c|c|}
\hline Mair & Events & Region & Name of Sample & Isotopic Age (Ma) \\
\hline \multirow{16}{*}{ 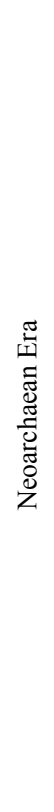 } & \multirow{5}{*}{ 氜 } & Labrador, Canada & Structured Kali granite & $2600 \pm 100$ \\
\hline & & West Greenland & Structured Kali granite & 2550 \\
\hline & & Wutaishan Mountain, China & E-Kou Granite & $2514 \mathrm{U}-\mathrm{Pb}$ \\
\hline & & Yilgarn, Australia & Structured Kali granite & 2600 \\
\hline & & Shanhaiguan, China & Structured Kali granite & $2600-2400 \mathrm{U}-\mathrm{Pb}$ \\
\hline & \multirow{6}{*}{ 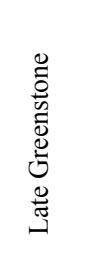 } & Ural District, Russian & Gneiss in Greenstone & $2700 \mathrm{U}-\mathrm{Pb}$ \\
\hline & & Superior, Canada & Greenstone Belt & $2650-2800$ \\
\hline & & Kambalda,Yilgarn, Australia & Greenstone Belt & $2790 \pm 30 \mathrm{Sm}-\mathrm{Nd}$ \\
\hline & & Brazil Massif & Schist in Greenstone & $2700-2900$ \\
\hline & & Zimbabwe, Africa & Greenstone Belt & $2600-2700$ \\
\hline & & Wutaishan Mountain, China & Wutai Greenstone Belt & $28002900 \mathrm{U}-\mathrm{Pb}$ \\
\hline & \multirow{5}{*}{ 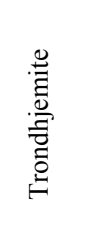 } & Intrusive Greenstone Belt, Southwest of Finland & Trondhjemite & 2800 - 2900 Zircon U-PB \\
\hline & & Intrusive Greenstone Belt, West Finland & Trondhjemite & $2800-2900$ Zircon U-Pb \\
\hline & & Intrusive Nuuk Gneiss, West Greenland & Trondhjemite & $3040 \pm 50 \mathrm{Rb}-\mathrm{Sr}$ Whole-Rock Isochrone \\
\hline & & Intrusive Qianxi Rock, Qian’an, Jidong, China & Trondhjemite & $2860-3010 \mathrm{~Pb}-\mathrm{Pb}$ Whole-Rock Model Age \\
\hline & & $\begin{array}{c}\text { Xiaolaihe Intrusive Granulite, Qingyuan, } \\
\text { Liaobei region, China }\end{array}$ & Trondhjemite & $2800-2900$ \\
\hline \multirow{11}{*}{ 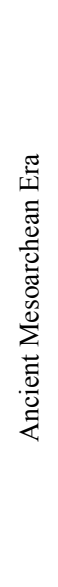 } & \multirow{5}{*}{ 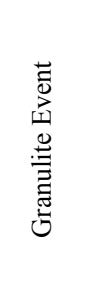 } & Limpopo Belt, South Africa & Granulite & 3150 \\
\hline & & Labrador, Canada & Granulite & $2800 \pm 200$ \\
\hline & & Aldan Massif, Russian & Granulite (Charnockite Deteroprate) & $2900-3010 \mathrm{U}-\mathrm{Pb}$ \\
\hline & & Antarctic Suonisi mountain & Granulite & $\geq 2948 \pm 31 \mathrm{U}-\mathrm{Pb}$ \\
\hline & & West Greenland & Granulite & $2800-2950 \mathrm{Rb}-\mathrm{Sr}$ \\
\hline & \multirow{6}{*}{ 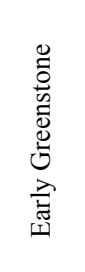 } & Dharwar Massif, South India & Dharwar Complex Greenstone & $3358 \mathrm{Rb}$-SR Whole-Rock Isochrone \\
\hline & & Pilbara Massif, Australia & Pilbara Complex Greenstone & $3450 \mathrm{Sm}-\mathrm{Nd}$ \\
\hline & & Qingyuan, China & $\begin{array}{l}\text { Xiaolaihe Greenstone Belt } \\
\text { Plagioclase Amphibolites }\end{array}$ & $3018 \pm 20 \mathrm{Sm}-\mathrm{Nd}$ Isochrone \\
\hline & & Anshan, China & Banded Magnet Quartzite & $3140 \mathrm{U}-\mathrm{Pb}$ \\
\hline & & Yilgarn massif, Australia & Quartz plagioclase gneiss & $3348 \pm 30 \mathrm{Rb}-\mathrm{Sr}$ \\
\hline & & Barberton, South Africa & Swaziland Complex Fulgurite & $3450 \pm 30 \mathrm{Sm}-\mathrm{Nd}$ Isochrone \\
\hline
\end{tabular}


rock (turbidites). In the Canadian greenstone belt, andesite accounts for $30 \%$ of rocks, but in the greenstone belt of Southern Africa and Australia, andesite only accounts for small-scale [11]. Their isotopic age was recorded about 2600 - 2900 Ma. The greenstone belts in Jiapigou of Jilin, Qingyuan of Liaoning, western Shandong Province region, Jiaodong region, and Jinbei region came into being during this period. For example, Sm-Nd isochron age of plagioclase amphibolites in Qingyuan greenstone belt was $2844 \mathrm{Ma}$ [12] (Shen et al., 1993).

\subsection{The Archean-Proterozoic Boundary and Cratonization}

Throughout the course of crustal evolution, the most remarkable change or the most important tectono-thermal event is the formation of the Archean-Proterozoic boundary and cratonization, that represent the most profound changes in earth evolution history, the finish of proliferation of early continental crust and the beginning of plate mechanism, have Epoch-making significance. Cratonization served to stabilize the continents and showed earthwide diachronism. The earliest rigid craton occurred 3.0 Ga ago, one example being the Kaapvaal Craton in South Africa, where were developed cover sediments dating back to 3.0 Ga. Both Mesoarchean and Neoarchean Eons proved critical to cratonization. Cratonization in North America, Greenland, Baltic, Australia and South Africa occurred at 2.7 to $2.8 \mathrm{Ga}$, whereas that in north India, north China and Brazil started at 2.45 Ga (Wang 1999) [2]. The formation and penetrating of abundant TTG rocks and their subsequent gneiss facies metamorphic differentiation are key factors in cratonization, and collision and collage of small continental crusts is a significant indicator for large-scale cratonization. Study of the non-deformed and non-metamorphosed mafic diabase dyke swarms centering around 2.6 to $2.7 \mathrm{Ga}$ in age concluded that continental crust at the time was already rather stable and apparently rigid [13]. These dyke swarms, extending up to thousands of kilometers, developed in cratons in North America, Australia, and north India, and melted within the crust at ca 2.5 to $2.6 \mathrm{Ga}$ on an earth-wide scale to form potassium-rich granite, which is nicknamed post-collision granite, for the simple reason that it was formed toward the end of cratonization set off by collision and coalition of numerous island arcs and microcontinents [14]. Potassium-rich granite formed by the intra-crust melting process symbolizes the maturity of crantons and may serve as a signpost for the ArcheanProterozoic boundary [15].

Most of the regions in China were affected by this movement, e.g. Taihangshan Mountain [16], Wutai Mountain [17], and Anshan region. It is the first large-scale continental-building period in the Precambrian of China, and by this movement the north of China formed the united, large-scale, rigid and stable North-China land mass [15].

\subsection{Research on the Evolution of Early Precambrian Crust and Plate Tectonics}

The formation and accretion of Archean crust remains a controversial topic in modern geological sciences, one of the debates being whether the Phanerozoic plate tectonics mechanism can be applied to the study of the Archean Eon in general and Mesoarchean and Early Archean in particular [18]. There is evidence that the plate tectonics theory, in a general sense, can be unquestionably applied to Neoarchean. Orogenic belts of inter-continental scale are found in both Neoarchean and Early Proterozoic; crustal structures resembling Phanerozoic orogenic belts are found in Early Proterozoic, where also identified are ophiolites typical of Early Proterozoic, such as Purtuniq ophiolite (1.988 Ga) in Canada, Jormua ophiolite (1.996 $\mathrm{Ga})$ in Finland, and Payson Ophiolite (1.73 Ga) in the US [19]. All these evidence strongly favors the application of the plate tectonic theory to Early Proterozoic, although evidence favoring Neoarchean plate tectonics is disputable. As pointed out by Hamilton (1985) [20], the Archean terrains do not have reliable equivalents to ophiolites, magmatic arcs, growth cones, and fore arc basins, all of which are associated with underthrusts and collisions in Phanerozoic plate tectonics.

Many geological records associated with collision and underthrust are found in both late Archean and early Proterozoic. North China Retained a wealth of late Archean collision orogeny records. The Neoarchean ductile shear zones and high-pressure granulite facies belts in northwest Hebei, China, are supposed to have resulted from collisions of terrains [21]. Petro-chemistry, trace element (including REE) and isotope data of Archean volcanic rocks indicate that such rocks from North China continental platform formed in a paleo-tectonic environment similar to modern island arcs and that they are primarily tholeiitic and, to a lesser degree, komatiitic [22]. Most of the North America craton resulted from collisions and welding of seven microcontinents and numerous island arcs at ca 1.8 to $2.0 \mathrm{Ga}$ to form a united craton [23]. Numerous U-Pb Zircon datings and field observations led to a collisional-orogenic model for the Early Proterozoic orogenic belt in west Greenland, assuming that the initial arc rock assemblages of Early Proterozoic thrust and overlaid the gneiss of Archean, and that Archean gneiss and Early Proterozoic upper crustal rocks alternated and superposed. In the north Australia craton, crustal accretion throughout Neoarchean and Early Proterozoic was controlled by underthrusts and lateral accretion. 
To sum up, the plate tectonics mechanism set to work definitely in Early Proterozoic and, with less certainty, also in Neoarchean - at least in processes related to plate tectonics, such as collisions. The commencement of processes related to plate tectonics and the workings of plate tectonics had a tremendous impact on the rapid crustal accretion. Throughout geological times, crustal accretion was uneven. Most of the present-day continental crust was formed in the Archean and the Proterozoic Eons.

\section{Main Geological Events of the Chinese Precambrian Eon}

Following the publication of Zhang Qinwen, Xu Daoyi, Mao Xueying (1984) many research papers appeared on the geological events in the Proterozoic Eon [24], e.g. from Lutai, North China [16], Zhongtiaoshan Mountain [25], Wutaishan Mountain [26], Luliangshan Mountain [27], and Taihangshan Mountain [6]. By analyzing the characteristic of the Bengbu Orogeny in Neoarchean, Longchuan Orogeny, Dikou Orogeny in the Paleoproterozoic, late-Mesopoterozoic Fengyang Orogeny, Shengong Orogeny in the end of Neoproterozoic, we think that the Fengyang and Shengong Orogenics result in the jointing of the North China, Yangtze and the Cathaysia paleo-plates. With these researches, the chronotectonic framework about main geological events in Lutai of North China and each featured districts in Precambrian Period were preliminarily established.

From the comparison between the sequence of main geological events in the Chinese Archaean (see Table 3) and the main geological events of the Archaean Eon elsewhere (see Tables 1-4), it is evident that most of these events were global, and all of these events have representatives in China. It also testifies to the irreversibility and periodicities of the development and evolution of the crust globally, and China as one of the most ancient continental crust regions developed in step with other most ancient continental cratons.

In addition, this comparison of events highlights the particularity and complexity of geological events of the Chinese Precambrian. For example, the middle-earlystage greenstone of the Archaean Eon lacked the true presence of komatiite, the mineral deposits in greenstone belts were also less profound than those of greenstone belts outside China; moreover, in the Proterozoic Eon the uranium conglomerate and tillites in China contain scarce gold and the plagioclase rocks of the Mesoproterozoic Era are rare. However in the Middle-Neoproterozoic Era there were some great biologic events recorded (see Table 3). And it also distinguished from other places worldwide, even the time period when it occurred would advance from several hundred million to ten million years. We should also indicate that in the Paleoprotero- zoic Era it was very rare to find magmatic activity in continents world-wide during the period from 2400 $2200 \mathrm{Ma}$, but in the north of China there are many such events accurately recorded (see Table 3). All of these events have spoken volumes for the particularity and complexity of geological events of the Chinese Precambrian.

To observe the performance of geological events of each region worldwide there are some obvious discrepancies and imbalance, such as the degree and timing of sequences of some geological events in southern hemisphere compared to the northern hemisphere. For instance in Early Archean greenstone events, the time of first appearance was much earlier and the metamorphic degree much lower in the southern hemisphere, while the time is much later and the metamorphic degree much higher in the northern hemisphere. To observe these geological events in a long-term direction, there is some obvious cyclicity and periodicity of Earth's rhythm [28]. For example, complete volcano-sedimentary cycles can be divided, which experienced the intrusion of sodium granites in the early Archean Era and intrusion of potassic granites in the late Archean Era. The Palaeoproterozoic Era basically could be regarded as a complete sedimentary cycle (it was a volcano-sedimentary cycle in China) which also was intruded by the potassic granites. The Chinese Middle-Neoproterozoic Era also formed a complete sedimentary-cycle, but the occurrence of main geological events in this period was mainly affected by the stability of the Earth's crust and increase of oxygen content (marked by the appearance of red beds and early animals).

\section{Conclusions}

As a result of the systematic analysis, we can conclude that:

1) A systematic review and comparison of the major geological events of worldwide Archean and Chinese Precambrian and their interrelationships reveals that these events show a spatial pattern of consistency, differentiation, and imbalance along with a temporal pattern of periodicity and cycles. The research conclusions above have important theory and application value to deeply systematic know the early dynamic evolution characteristics and the geological environment evolution law and geological mineral resources formed enrichment law of the earth.

2) The comparison between the Chinese Precambrian major geological events and the Archean worldwide ones indicates that major geological events tended to unfold on a global scale and that crustal evolution showed considerable irreversibility, gradualism, and synchronism. Specifically, the stages of the Archean crustal evolution 
Table 3. The sequence of great Chinese Precambrian geological events.

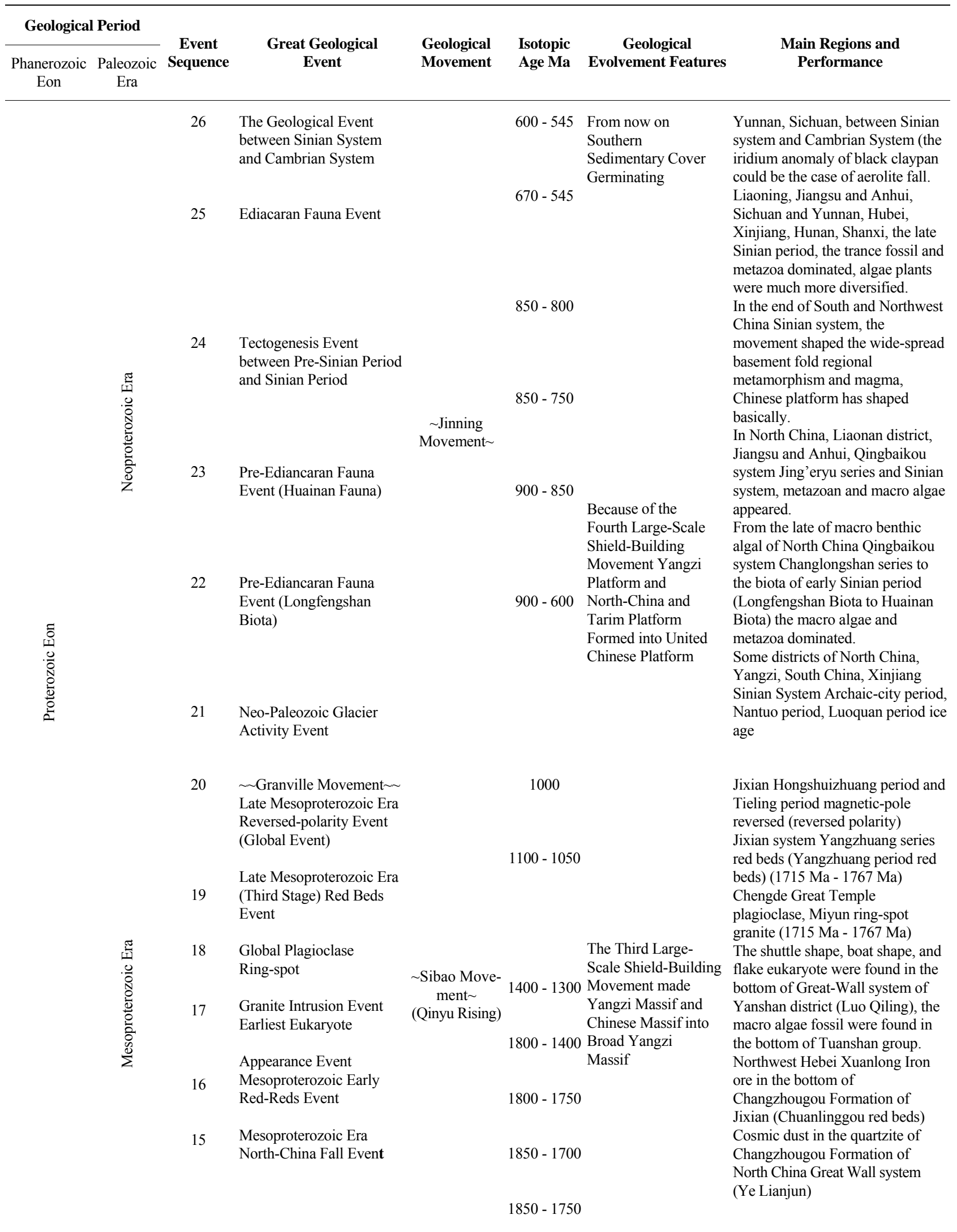




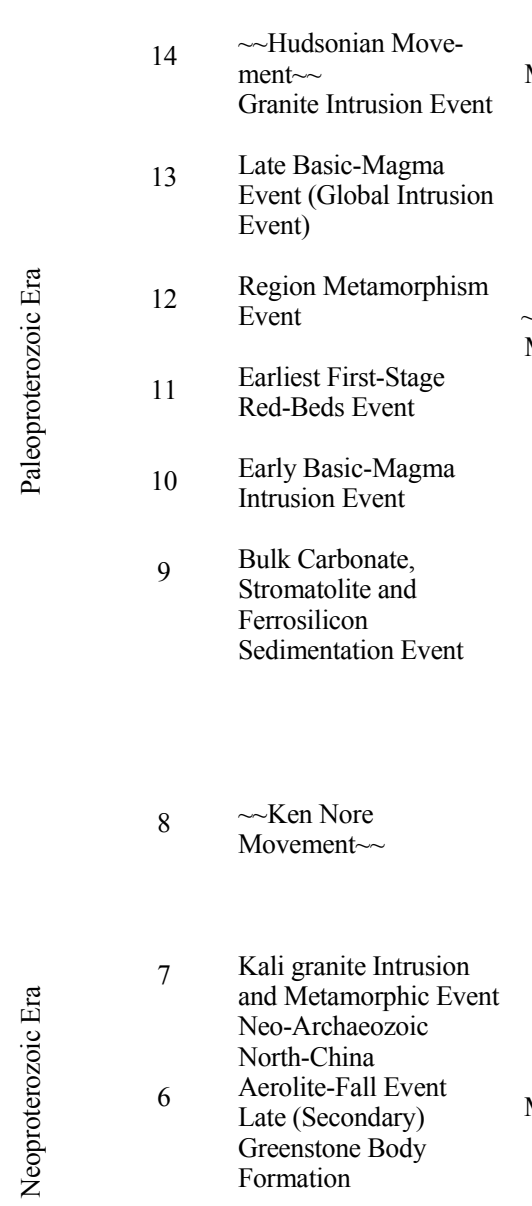

Lvliang rock body (rifting period granite), Liaonan granite, Shanxi Fenghuangshan Lotus rock body In the middle and north of China and Sichuan and Yunnan district (rifting) there were a lot of basic and ultrabasic magma activities.

$2000-1900$

The Second Large-Scale Shield-Building

The early Lvliang activities made the early Proterozoic stratum of Jidong distict suffered $\begin{array}{lll}\text { Qinglonghe } 2100-2000 & \begin{array}{l}\text { Movement Made } \\ \text { Movement }\end{array} & \text { North-China Massif and } \\ \text { greenschist facies regional }\end{array}$ Tarim Massif United.

metamorphism.

Zhongdoucun Subpopulation Slate of Hutuo Group, Songshan Group red beds (Hutuo period red beds) the deep-seated fault of Archean Eon Craton, such as Huairou of Beijing,

Zhongtiaoshan, Taihangshan mountain, Wutaishan Mountain. The formation of Hutuo group, Shuangzishan Group, Qinglonghe Group, Zhongtiao group, Lanhe group, Liaohe group, Fenzishan group.

Wutaishan rock body, Ekou granite, Lanzhishan Granite. Gongchangling granite. Qian'an Xingshan granite, this movement was the large-scale region metamorphic, migmatite,

$2600-2500$

large-scale kali granite intrusion and diastrophism, all of these shaped the North-China land mass. $\begin{gathered}\sim \text { Wutai } \\ \text { Movement }\end{gathered} 3000-2900 \begin{aligned} & \text { united North-China } \\ & \text { massif (or continenta }\end{aligned}$ 2600 - 2500 The first time large-scale 2800 - 2700 shield-building movement formed the 2970 - 2829 massif)

The cosmic dust of Xiahuo rock series, Jiaodong rock series, Jianping rock series (Yan Jincai) Qingyuan Rock series,

Shang'anshan rock series, Wutaishan rock series, Dengfeng rock series, Taishan rock series, Fuping rock series, Wulashan rock series, Jining rock series, Miyun rock series

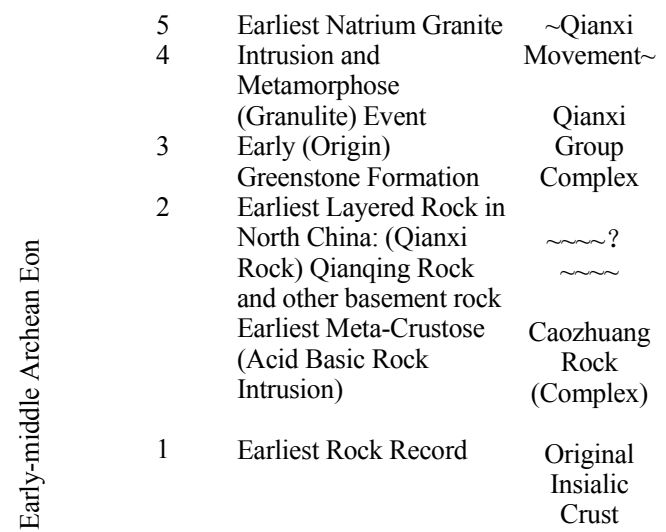

3000

$>3000$

Important structure-heat event in Archean Eon

3500 Ling- Shaping the original zhi Opera- massif (Early Continent)

tion by jointing the continental 3500 - 3600 nuclear and greenstone belt Shaping I volcanic

$3800-3850$ sediment cycle around the continental sediment. Qianxi complex depositing on Caozhuang Formation.

First tectonic-thermal event (acidic rock intrusion, basic rock intrusion) (Original continental formation)

Caozhuang formation depositing on original crust

Original sal-crust

formation stage.
Liaonan Anshan Tiejiashan Granite, Qingyuan Granite, Qianxi Granite, and obvious performance of Qianxi movement in Qingyuan (Jingjiagou series and Qingyuan rock series not united. Liaoning Qingyuan Xiaolaihe greenstone belt (Qingyuan Jiaojiagou Series).

Xia'anshan rock series, Longgang rock series, Sanggang rock series, Jiaole rock series, Yishui rock series. The Formation of Jidong Original Small Continental Nuclear and Huai'an Old Land. Hebei Qian'an Water-work Belt High-grade Metamorphic Rock Series.

Anshan Trondhjemite, Jidong fuchsite quartzite. 
Table 4. Stages of China and the World Precambrian Evolution and the formation and breakup of pan-continental.

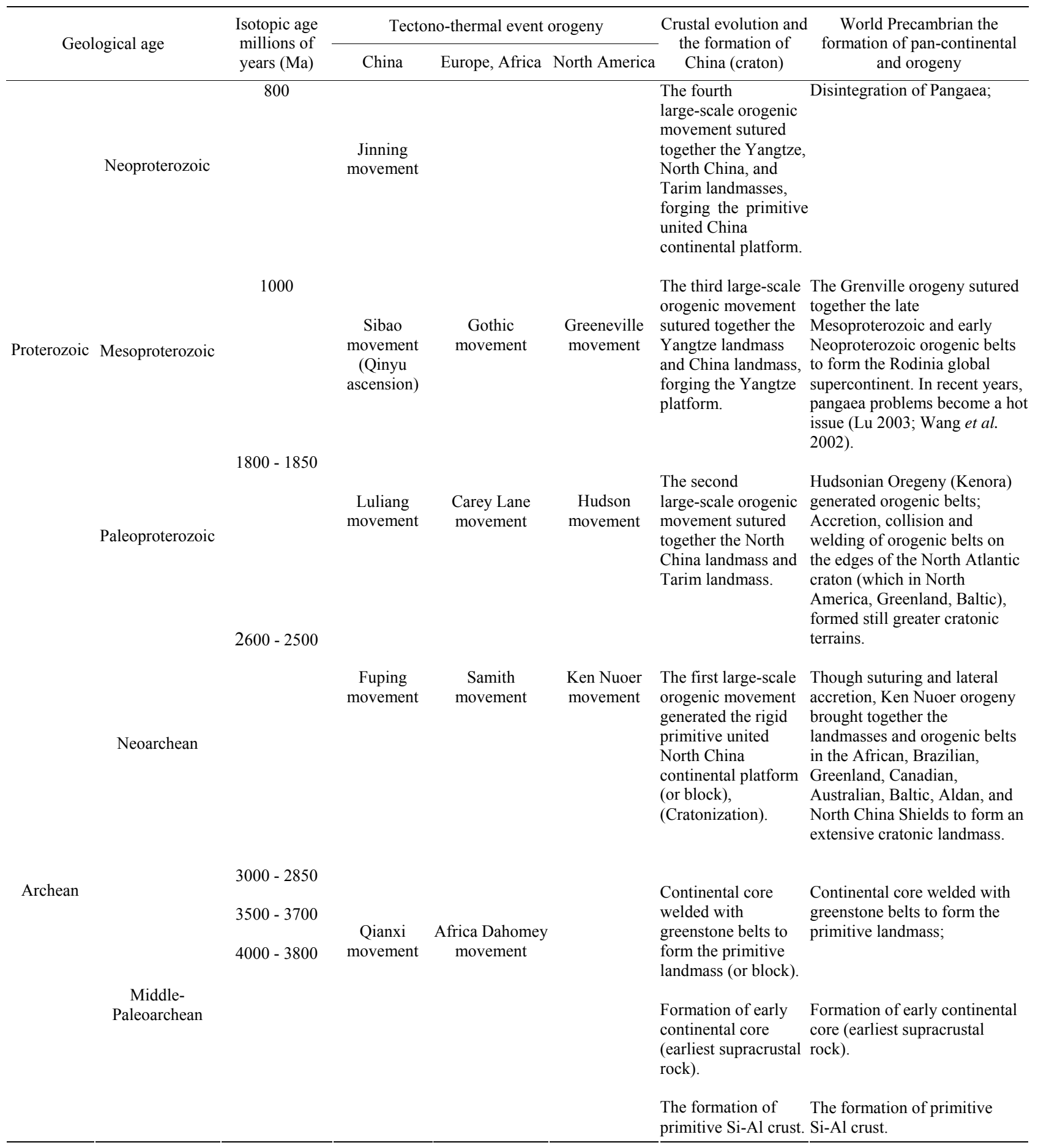

across the earth roughly coincided with each other (see Table 4); all old landmasses (cratons) are composed of granite-greenstone belts and high-grade gneiss (granulite) terrains, featuring universal multiple-stage metamorphism of various degrees, structure characterized by flat "gneiss domes" and oval structures and ductile shear zones, universal violent magmatism, dominated by acid in- trusion at both the early and the late stages, and roughly synchronized major orogenic movements.

3) The major geological events exhibit striking differentiation and imbalance across the ancient lands. For example, both the time when the Archean cratonization occurred and the degree of the resulted metamorphism vary widely from land to land. Cratonization in South 
Africa, Australia, Antarctica, and North America was earlier or the earliest and resulted in a lower degree of metamorphism; whereas cratonization in North China, Russia and India occurred at a later time and led to a higher degree of metamorphism. The differentiation of the degree of metamorphism in early global different areas decided the great differentiation of enrichment and distribution of the metamorphic dynamic mineral in different regions.

4) The time when the geological events occurred shows a remarkable cyclical pattern periodicity or geological rhythm. For example, the formation of the Archean Pangea or Supercontinent appears to be cyclical, with supposedly $250 \mathrm{Ma}$ to $350 \mathrm{Ma}$ as a cycle; magmatism is also cyclical, characterized by intrusion of primarily sodic granite at the early stage and by primarily potassic granite at the late stage, the same cyclical pattern is also found in the Proterozoic Era. Both PaleoMesoarchean and Neoarchean host a complete vovanicsedimentary cycle (sequence recovery of greenstone belts). Likewise, both Paleoproterozoic and Meso-Neoproterozoic host two complete vocanic-sedimentary cycles.

5) The Precambrian major geological events in China are comparable to those in elsewhere on the earth but also have their unique features. China has a relatively complete record of formation and evolution of rocks, strata, structures, and organisms spanning $3800 \mathrm{Ma}$ to $540 \mathrm{Ma}, 1400 \mathrm{Ma}$ ago Macro-biological appeared [29], $800 \mathrm{Ma}$ to $900 \mathrm{Ma}$ ago, Macroscopic multi-cellular complex biological appeared (Longfengshan Biota) [30]. The Archean underwent multiple-stage complex metamorphism and deformation; metamorphism is on the higher end; komatite is absent in the greenstone belts; cratonization occurred rather late and varied between the north and the south.

\section{Acknowledgements}

The research discussed in this article was sponsored by the Special Research Foundation of the Department of Education (No. 20113721110002), the Open Research Foundation of Water Resources and Hydropower Research of China (IWHRKF 2010119) and the National Natural Science Foundation of China (No. 40672182 and 40872184). In the process of conducting this research programme, postgraduate students, Wang Lihong, Li Xinyuan and Jinwen, have assisted us in gathering data, and would like to extend our warmest gratitude to them.

\section{REFERENCES}

[1] P. D. Kinny, D. O. William and T. R. Froude, "Early Archaean Zircon Ages from Orthogneisses and Anorthosites at Mount Narryer Western Australia," Precambrian Re- search, Vol. 38, No. 4, 1988, pp. 325-341. doi:10.1016/0301-9268(88)90031-9

[2] T. Y. Wang and M. J. Zhang, "Review on the Progress in the Study of Early Precambrian Geology," Journal Lanzhou University, Vol. 35, No. 3, 1999, pp. 164-171.

[3] P. D. Kinny, "Ma Zircons from a Tonalitic Amitsoq Gneiss in the Godthab District of Southern West Greenland," Earth and Planetary Science Letters, Vol. 79, No. 3-4, 1986, pp. 337-347. doi:10.1016/0012-821X(86)90190-1

[4] S. A. Borvring, T. B. Housh and C. E. Isachsen, "The Acasta Gneisses: Remnant of Earth's Early Crust," In: Origin of the Earth, Elsevier, Amsterdam, 1990, pp. 319 343.

[5] V. R. McGregor, "The Early Precambrian Gneisses of the Godthab District, West Greenland," Philosophical Transactions Royal Society London, Series: A, Vol. 273, No. 1235, 1973, pp. 343-358.

[6] D. Y. Liu, A. P. Nutman and W. Compston, "Remnant of > 3800 Ma Crust in the Chinese Part of the Sino-Korean Craton Geology," Acta Geoscientica Sinica, Vol. 20, No. 4, 1994, pp. 339-342.

[7] C. R. Anhaeusser, "Geotectonic Evolution of the Archaean Successions in the Barberton Mountain Land, South Africa," In: A. Kroner, Ed., Precambrian Plate Tectonics, Elsevier, Amsterdam, 1981, pp. 137-160.

[8] A. Y. Glikso and B. Lambert, "Vertical Zonation and Petrogenesis of the Early Precambrian Crust in Western Australia," Tectonophysics, Vol. 30, No. 1-2, 1976, pp. 5584. doi:10.1016/0040-1951(76)90137-2

[9] B. F. Shen, J. J. Li and D. B. Mao, "The Type and Evolvement of Greenstone Belt Geology in North China Platform," In: The 30th International Geological Conference Symposia, Geological Publishing House, Beijing, 1998, pp. 229-235.

[10] J. Bai, X. G. Huang and F. Y. Dai, "China Precambrian Crust Evolution," The Geological Publishing House, Beijing, 1993, pp. 20-22.

[11] B. F. Windley, "Precambrian Rocks in the Light of the Plate Tectonic Conept," Elservier, Amsterdam, 1981, p. 781.

[12] B. F. Shen, X. L. Peng, H. Luo and D. B. Mao, "Archean Greenstone Belts in China," Acta Geological Siniea, Vol. 67, No. 3, 1993, pp. 208-220.

[13] X. L. Qian, "The Nature of the Early Precambrian Continental Crust and Its Tectonic Evolution Model," Acta Petrologica Sinica, Vol. 12, No. 2, 1996, pp. 169-177.

[14] X. Liu, L. Yao and P. Zheng, "Origin of Potassium Events on Archean Terrain from Southern Jilin, China," Global Geology, Vol. 25, No. 3, 2006, pp. 259-263.

[15] Z. P. Zhao, "Subdivision of Precambrian Time and RockStratigraphic Units of Eastern China: Inference from Precambrian Crustus Evolution of Eastern Hebei Province," Scientia Geologica Sinice, Vol. 4, No. 4, 1988, pp. 301312.

[16] J. S. Wu, Y. S. Geng and Q. H. Shen, "Great Geological Event of Precambrian in North China Platform," The Geological Publishing House, Beijing, 1991, pp. 43-48. 
[17] Y. S. Liu, H. F. Yu, H. T. Xin, S. N. Lu, Q. Y. Xiu and Q. Li, "Tectonic Units Division and Precambrian Significant Geological Events in Altyn Tagn Mountain, China," Geological Bulletin of China, Vol. 28, No. 10, 2009, pp. 1430-1438.

[18] Y. J. Ye, G. G. Wu and D. Zhang, "Advances in Earth Origin and Evolution," Geoscience, Vol. 7, No. 2, 2003, pp. 119-124.

[19] J. H. Li, X. N. Huang, X. L. Qian and S. W. Liu, "Current Situation in Study on the Archean-Proterozoic Boundary," Geological Journal of China Universities, Vol. 7, No. 1, 1988, pp. 43-49.

[20] H. J. Hofmann, "The Mid-Proterozoic Little Dal Microbiota, Mackenzie Mountains, North-West Canada," $\mathrm{Pa}$ laeontology, Vol. 28, No. 3, 1985, pp. 331-354.

[21] J. H. Li, G. T. Hou and S. J. Liu, "The Early Precambrian Collisional Orogenic Process and Plate Tectonics Chance and Challenge of Precam Brian," Geology Advances in Earth Science, Vol. 21, No. 8, 2006, pp. 843-847.

[22] W. L. Yu, J. M. Zhang and G. Y. Zheng, "The Geological Evolution and Mantle Convection of the North China Platform in Early Precambrian," Journal of Northeastern University, Vol. 17, No. 7, 1996, pp. 348-351.

[23] H. J. Hofmann and J. W. Schopf, "Early Proterozoic Microfossils," In: J. W Schopf, Ed., Earth's Earliest Biosphere: Its Origin and Evolution, N. J. Princeton University Press, Princeton, 1983, pp. 321-360.
[24] Q. W. Zhang, D. Y. Xu and X. Y. Mao, "The Geological Event between Precambrian and Cambrian Period, International Communication Geological Academic Paper 1 (For 27th International Geological Conference)," The Geological Publishing House, Beijing, 1984, pp. 143-150.

[25] D. Z. Sun, H. M. Li and Y. X. Lin, "Zhongtiaoshan, Precambrian Chronology, Age Tectonic Framework and Age Crust Structure Model," Acta Geologica Sinica, Vol. 65, No. 4, 1991, pp. 216-231.

[26] J. Bai, R. Z. Wang and J. J. Guo, "Great Geological Event and Its Age in Precambiran Wutaishan," The Geological Publishing House, Beijing, 1992, pp. 23-26.

[27] Y. S. Geng, Y. S. Wan and Q. H. Shen, "Chronological Framework of the Early Precambrian Important Events in the Lvliang Area," Geognosy Journal, Vol. 74, No. 3, 2000, pp. 216-223.

[28] H. Z. Wang, "The Thoughts about Rhyme of Earth and Continental Dynamics," Earth Science Frontier, Vol. 4, No. 4, 1997, pp. 1-12.

[29] M. R. Walter, R. L. Du and R. J. Horodyski, "Coiled Carbonaceous Megafossils from the Middle Proterozoic of Jixian (Tianjin) and Montana," American Journal of Science, Vol. 290, No. 2, 1990, pp. 133-148.

[30] R. L. Du and L. F. Tian, "The Neoproterozoic Qingbaikou Period Longfengshan Biota," Science Press, Beijing, 2009, pp. 1-139. 